\title{
UTILIZATION OF WASTE-BASED SORBENTS FOR REMOVAL OF PHARMACEUTICALS FROM WATER: A REVIEW
}

\author{
Lenka BLINOVÁ ${ }^{1}$, Maroš SIROTIAK ${ }^{1}$ \\ ${ }^{1}$ SLOVAK UNIVERSITY OF TECHNOLOGY IN BRATISLAVA \\ FACULTY OF MATERIALS SCIENCE AND TECHNOLOGY IN TRNAVA \\ INSTITUTE OF INTEGRATED SAFETY \\ Ulica JÁna BotTu 2781/25, 91724 TRNAVA, SLOVAK REPUBLIC \\ e-mail: lenka.blinova@stuba.sk,maros.sirotiak@stuba.sk \\ Received 28 April 2021, Accepted 1 June 2021, Published 20 July 2021
}

\begin{abstract}
Nowadays, the water contamination which is due to pharmaceuticals is increasing and alarming. The pharmaceuticals in water are very hazardous and toxic not only for the human life but also for environment. One of the promising methods of removing pharmaceuticals from the contaminated water is adsorption. Agricultural and industrial wastes or by-products can be used as low-cost adsorbents for pharmaceuticals removal. Low-cost adsorbents provide particular economic and environmental advantages. This paper presents an overview of utilizing of the waste-based adsorbents (mainly spent coffee grounds) for the removal of pharmaceuticals from water.
\end{abstract}

\section{Keywords}

Pharmaceuticals, tetracycline, adsorption, waste utilization, spent coffee grounds

\section{INTRODUCTION}

Water is the most important substance for life on Earth, and access to drinking water is a major global challenge for the $21^{\text {st }}$ century. Pure and uncontaminated water is the basic prerequisite for all living organisms [1]. Over the years, quality of water keeps deteriorating, which is due to the anthropogenic activities, population growth, rapid industrialization, unskilled utilization of natural water resources, etc. [2]. The presence of toxic metals, dyes, pharmaceuticals and microorganisms even in the trace amounts is very dangerous to the human and animal health as well as the environment $[1,3]$. Pharmaceutical compounds pose a major environmental problem, since they have been detected in all aquatic environmental matrices, including drinking water, surface water, groundwater, wastewater treatment plants effluents and landfill leachates in many different countries [3,4]. Potential toxicity, high persistency and low biodegradability are the most important features of numerous pharmaceuticals. Prolonged 
exposure to those compounds (also at low concentrations) could cause irreversible and longterm changes to the microorganisms genome and behaviour of aquatic organisms [3].

Various methods (such as filtration, oxidation, precipitation, coagulation, flotation, distillation, evaporation, reverse osmosis, electro-chemical, ion exchange and adsorption) developed and used for water treatment may be applied for the removal of pharmaceuticals. Adsorption is considered as one of the appropriate methods for removal of contaminants, as it has a lot of advantages, (e. g. easy operation, and a wide range of adsorbents that can be used for removal of different pollutants) [5]. Cost analysis is one of the most important criterion for the selection of a water treatment method. Cost of adsorption methods depends on the cost of the used adsorbent [6]. Therefore, low-cost adsorbents (wastes or byproducts from the agricultural, household, and industrial sectors) have been recognized as a sustainable solution to water treatment. They allow the removal of contaminants (such as pharmaceuticals, toxic metals and dyes) from water, and at same time they contribute to the waste minimization, recovery and reuse [2].

\section{PHARMACEUTICALS IN THE ENVIRONMENT}

Pharmaceuticals are synthetic or natural chemicals which contain active ingredients that have been designed to have pharmacological effects and confer significant benefits to society. They generally include prescription medicines or over-the-counter drugs, veterinary or human drugs as well as nutraceuticals administered for the prophylaxis/therapeutic and health supplements purposes [7, 8].

Pharmaceuticals are generally classified based on the therapeutic use, the ways they work in the body (pharmacological effect), and chemical groups [8]. They can be classified into different active organic groups of compounds including, but not limited to, (i) antibiotics (e.g. penicillin, tetracycline, clarithromycin, sulfonamides, macrolides, fluoroquinolones, chloramphenicol), (ii) steroids hormones (e.g. estrogens, estrone, estriol, 17- $\beta$-estradiol, 17- $\alpha$ ethinylestradiol, testosterone), (iii) analgesic and non-steroidal anti-inflammatory drugs (e.g. acetaminophen, diclofenac, ibuprofen, naproxen, acetaminophen), (iv) antiepileptic drugs (e.g. carbamazepine, primidone), (v) blood lipid regulators (e.g. bezafibrate, gemfibrozil, fenofibric acid, clofibric acid), (vi) $\beta$-blockers (e.g. salbutamol, atenolol, sotalol, theophylline, metoprolol, propanolol), (vii) antineoplastic/cytostatic drugs (e.g. ifosfamide, cyclophosphamide), (viii) contrast media (e.g. diatrizoate, iopromide) [9, 10]. According to [9], pharmaceuticals also include antimicrobial agents, fungicides, disinfectants, synthetic musks, some preservatives, some sunscreen UV filters, etc. However, it depends on the description of use.

Pharmaceutical industry is responsible for the research, development, production and distribution of drugs. The market has experienced significant growth during the last two decades. Revenue of the worldwide pharmaceutical market was totalled 1,250.4 billion U.S. dollars in 2019 (963.2 billion U.S. dollars in 2011, 390.2 billion U.S dollars in 2001) [11, 12]. Based on this information and also according to [13], the global pharmaceutical market (consumption of pharmaceuticals) is expected to keep growing in the upcoming years, which is due to several reasons, e.g. population's age and life-span increase; economy growth particularly in emerging economies - and, along with it, an increasing ability and expectations to treat the ageing-related and chronic diseases; emergence of new diseases; the engineering of new pharmaceuticals; exacerbation of existing diseases due to climate change (noncommunicable diseases and respiratory, water-borne, vector-borne and food-borne toxicants and infections are expected to become more common as climate change intensifies); use of pharmaceuticals for medical prophylaxis and therapy and for viability sustenance of commercial aquaculture and livestock agriculture $[9,13,14]$. 
Pharmaceuticals (drugs) are continuously released into wastewater via urine, and faeces (through sewage) as parent compounds, derivative conjugates or metabolites. They can be introduced into the aquatic environment through direct discharge from industries, hospitals, domestic wastewater, through agricultural runoff comprising livestock manure, from incorrect disposal of unused pharmaceuticals (e.g. discarding drugs into municipal waste and then their accumulation into landfills, discarding drugs into toilets), from irrigation with wastewater, from disposal of carcasses of treated animals, etc. (Figure 1). The main route through which pharmaceuticals are discharged into the aquatic environment are wastewater treatment plants (WWTPs) [7, 9].

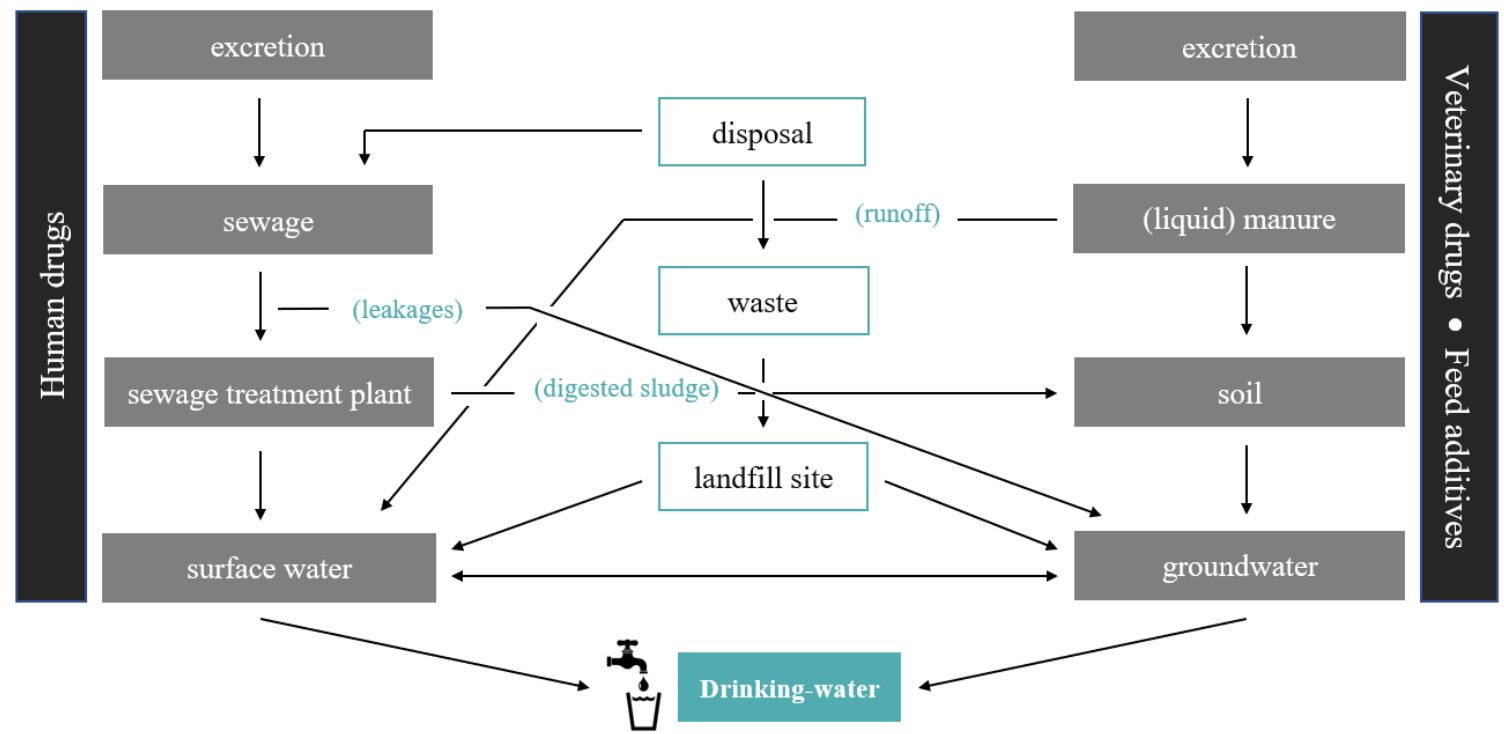

Figure 1 Fate and transport of drugs in the environment. Adapted from [15].

More than $80 \%$ of pharmaceuticals are released into the environment from the human body without transformation (i.e. in the parent form un-metabolized). These are fed through into the WWTPs for removal or decomposition during the water treatment process [9]. WWTPs play an important role in removal of harmful contaminants (such as pharmaceuticals) from wastewater, although most pharmaceuticals, hormones and their metabolites cannot be completely removed by the processes used in WWTPs (efficiency of most WWTPs range between 50-90 \%) [16]. Conventional WWTPs are not designed to, nor do they fully remove pharmaceuticals from wastewater. Therefore, pharmaceuticals have been found as residues in sediments, sludge, lakes, rivers, groundwater, marine, coastal area waters, and drinking water [7, 9, 14, 16].

Chemical persistence, microbial resistance and synergistic effects of pharmaceuticals are still unknown. Despite the fact that pharmaceuticals are found in the environment at trace concentrations, there is a cause for concern. Certain pharmaceuticals in water environment have been proven to cause undesired adverse effects to ecosystems, including mortality, as well as changes to physiology, behaviour, and reproduction [14, 17]. Some of the greatest concerns are hormones, antibiotics, analgesics, antidepressants and anticancer pharmaceuticals used for human health; as well as hormones, antibiotics and parasiticides used as veterinary pharmaceuticals [14].

Table 1 shows the examples of adverse effects of certain pharmaceuticals in the environment on aquatic organisms as well as the human and animal health [14]. 


\begin{tabular}{|l|l|}
\hline \multicolumn{2}{|l|}{$\begin{array}{l}\text { Table 1 Examples of adverse effects of certain pharmaceuticals in the environment on aquatic } \\
\text { organisms, and human and animal health [14] }\end{array}$} \\
\hline Therapeutic group & \multicolumn{1}{c|}{ Impact and effected organisms } \\
\hline Analgesics & $\begin{array}{l}\text { Organ damage, reduced hatching success (fish) } \\
\text { Genotoxicity, neurotoxicity, and oxidative stress (mollusc) } \\
\text { Disruption in hormones (frog) }\end{array}$ \\
\hline Antibiotics & $\begin{array}{l}\text { Reduced growth (environmental bacteria, algae, and aquatic plants) } \\
\text { Indirect effects of antibiotic resistance (humans and animals) }\end{array}$ \\
\hline Anticancer & $\begin{array}{l}\text { Genotoxicity } \\
\text { Mutagenicity, carcinogenicity, toxicity to foetus }\end{array}$ \\
\hline Antidiabetics & Potential endocrine-disrupting effects (fish) \\
\hline Anticonvulsants & Reproduction toxicity (invertebrates), development delay (fish) \\
\hline Antifungals & $\begin{array}{l}\text { Reduced growth (algae, fish), reduced algae community growth } \\
\text { Disruption with hormones (mammals including humans) }\end{array}$ \\
\hline Antihistamines & $\begin{array}{l}\text { Behaviour changes, growth and feeding rate (fish) } \\
\text { Behaviour changes and reproduction toxicity (invertebrates) }\end{array}$ \\
\hline Antiparasitics & Growth and reduced reproduction (invertebrates) \\
\hline$\beta$-blockers & Reproduction behaviour (fish), reproduction toxicity (invertebrates) \\
\hline $\begin{array}{l}\text { Endocrine disrupting } \\
\text { pharmaceuticals }\end{array}$ & $\begin{array}{l}\text { Disruption with hormones causing reproduction toxicity (fish, frogs) } \\
\text { Increased risk of breast or prostate cancer (humans) }\end{array}$ \\
\hline Psychiatric dugs & $\begin{array}{l}\text { Behaviour changes - feeding, boldness, activity, sociality (fish) } \\
\text { Disruption in hormones (fish) } \\
\text { Behaviour changes - swimming and cryptic (invertebrates) } \\
\text { Reproduction toxicity and disruption with hormones (invertebrates) }\end{array}$ \\
\hline
\end{tabular}

Of the pharmaceuticals, special attention should be paid to antibiotics (used to prevent and treat bacterial infections), since their consumption per capita increased by $39 \%$ worldwide between 2000 and 2015 [18, 19, 20]. The biggest problem is that antibiotics can persist in the environment, as they have been detected in water resources. There is a growing concern that residues of antibiotics in the surface water may pose a risk to human health by promoting antibiotic resistant bacteria and antibiotic resistance genes. Furthermore, antibiotics in ecosystems can have impact on the evolution of microbial structure, thus posing a risk to ecological health [18]. According to [19], antibiotic resistance results in the following facts: it is one of the biggest threats to global health, food security and development today; it can affect anyone, of any age, in any country; it occurs naturally, yet the misuse of antibiotics in humans and animals is accelerating the process; a growing list of infections (such as pneumonia, tuberculosis, blood poisoning, gonorrhoea, and foodborne diseases) that are becoming harder and sometimes impossible to treat, as antibiotics become less effective; it leads to longer hospital stays, higher medical costs and increased mortality.

The adverse effects of pharmaceuticals are the main reason why it is necessary to find the effective treatment methods for removal of pharmaceuticals from water environment.

\section{ADSORPTION AS A PROCESS FOR REMOVAL OF PHARMACEUTICALS}

There is a lot of methods that can be used for removal of pharmaceuticals from various water media [5]. Generally, wastewater treatment methods are categorized into physical and 
physico-chemical, chemical, and biological processes. Another group represents the methods which use a combination of the above-mentioned processes [21, 22]. These treatment methods can also be divided into:

- Conventional treatment methods (e.g. coagulation, sedimentation, flocculation, flotation, ion exchange, adsorption, conventional activated sludge, membrane bioreactor, constructed wetland),

- Advanced treatment methods (e.g. activated carbon adsorption; membrane filtration: reverse osmosis, ultrafiltration, nanofiltration),

- Advanced oxidation processes - AOPs (e.g. wet air oxidation, supercritical water oxidation, Fenton oxidation, photocatalytic oxidation, ultrasound oxidation, electrochemical oxidation, ozonation) $[5,9,21,22,23,24,25]$.

Each of these treatment methods has its advantages and disadvantages that may sometimes limit their application in certain cases (e.g. costs, high energy consumption or formation of toxic by-products) $[22,26]$. Some of these methods are more efficient and effective in removing pharmaceuticals compounds of interest than others. [9] The removal efficiency of different pharmaceuticals varies greatly and depends on the physical and chemical properties of the parent compounds, hydrophobicity, biodegradability of target pharmaceuticals, used treatment methods, etc. [9, 27].

Pharmaceuticals cannot be thoroughly removed in wastewater treatment plants (WWTPs), and therefore they have been detected in surface water, ground water, WWTP influent and effluent, urban effluent and hospital effluent [22]. Limited efficiency of WWTPs could be attributed to the fact that they use conventional biological wastewater treatment processes. [9][16] It is necessary to find efficient methods for removing pharmaceuticals from surface water and groundwater, and to minimize the discharge of pharmaceuticals from the WWTPs [27]. It would be appropriate if these methods would be also applicable to the existing WWTPs.

One of the methods, which has been widely utilized for removal of pharmaceuticals from water environment is adsorption process. Adsorption can be defined as a process that occurs when a gas or liquid solute bind to the surface of a solid or a liquid (adsorbent) $[1,28]$. The substance that concentrates at the surface of adsorbent is called adsorbate. Type of adsorption (physical and chemical adsorption) depends on the type of attractions between adsorbate and adsorbent [1].

Adsorption has certain advantages in comparison with other methods, because the removal of contaminants is easy to design and operate (technologically simple and adaptable to many treatment formats, it works at mild operation conditions and at a wide $\mathrm{pH}$ range), the process does not produce any toxic by-product, requires low energy, it is efficient and cost-effective, a wide range of products can be used as adsorbent (commercial materials, waste materials or byproducts), it can be used for a wide variety of target contaminants, etc. [17, 26, 27, 29]. Adsorption has also some disadvantages such as relatively high investment and cost of materials (valid for adsorbents such as commercial activated carbons, commercial activated alumina), it can be inefficient with inappropriate combination of contaminant and adsorbent, more types of adsorbents can be needed in the process, adsorbents require regeneration, the process produces waste, etc. [29, 30, 31]. Cost effectiveness of adsorption process depends on the used adsorbent and its treatment. If waste materials are used as an adsorbent, the process will be cheaper, but if commercial adsorbents or adsorbents which need treatment were used, the process would be more expensive and economically non-viable.

Performance of an adsorption process is affected by a characteristic feature of adsorbent [17]. An effective adsorbent must have numerous properties - inertness, biocompatibility, resistance to mechanical forces, high surface area and high hydrophobicity, 
while exhibiting a high adsorption capacity to be effective in the contaminants removal. These properties are important, since they can determine utilisation of the material. Efficiency of adsorption processes also depends on the type of adsorbent, pore size and particle size of adsorbent, temperature, $\mathrm{pH}$, concentration and type of contaminant, existence of competing organic or inorganic compounds in solution, contact time and speed of rotation, ionic strength of solution, as well as the physical and chemical nature of the adsorbate and adsorbent, etc. [1, $25,26,32]$.

Various adsorbent materials (Figure 2) can be used for the removal of various types of contaminants (e.g. toxic metals, dyes, pharmaceuticals) from aqueous solution.

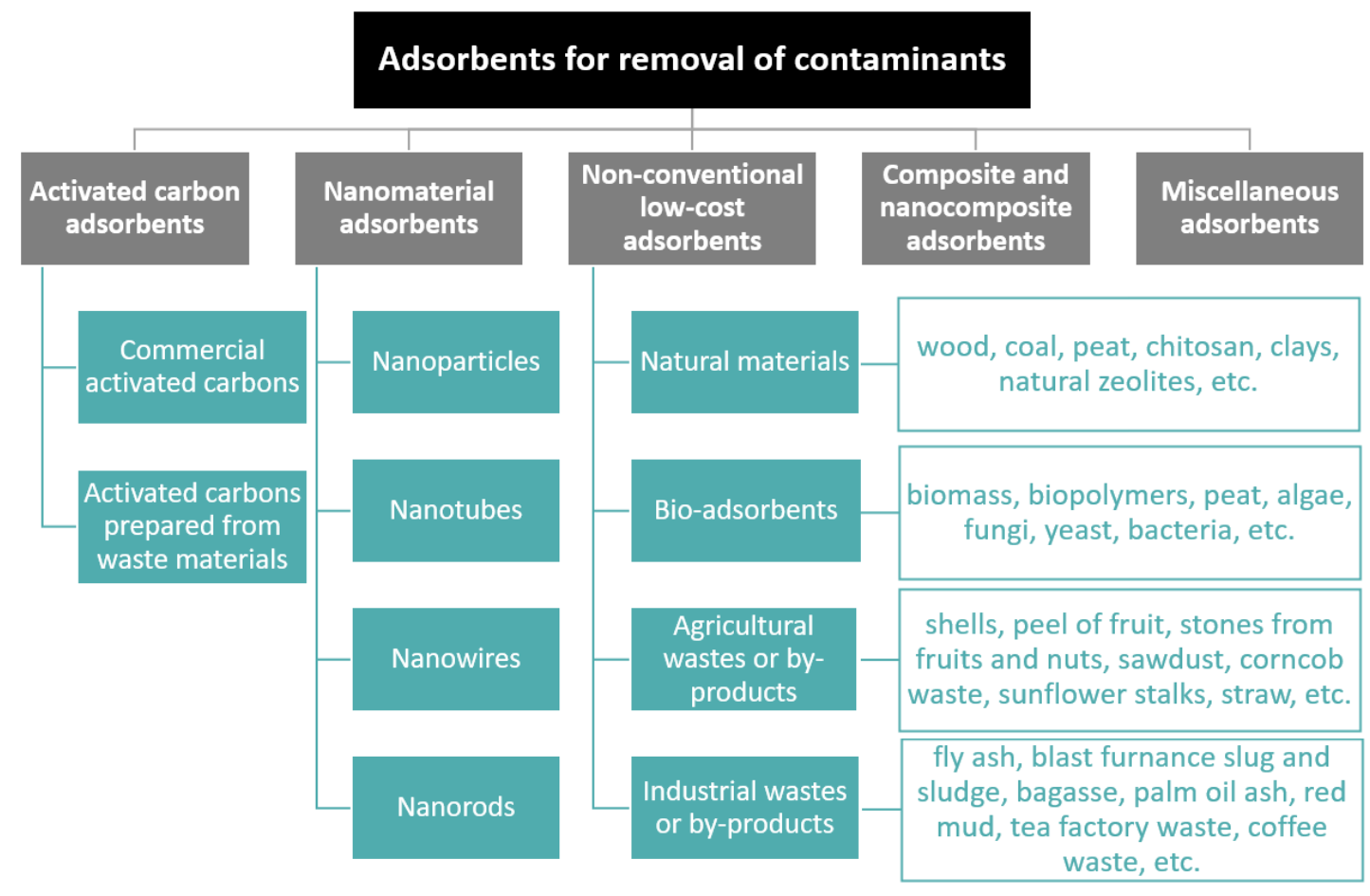

Figure 2 Adsorbents for removal of contaminants from aqueous solution. Adapted from [1].

The most commonly adopted adsorbent used for the removal of various contaminants from water is activated carbons (AC). Its widespread use in wastewater treatment is sometimes restricted due to its higher cost and its low adsorption efficiency of trace organic contaminants $[2,27]$. Adsorption which uses commercial AC is well-suited to removing organic compounds, specifically pharmaceuticals, which is due to their high specific surface (more than $400 \mathrm{~m}^{2} \mathrm{~g}^{-1}$ ), and the combination of a well-developed porous structure and the surface chemistry properties [4].

Generally, the aim is to use low-cost materials for adsorption (such as the agriculture and industry waste or by-products, household waste) instead of AC. These wastes or by-products currently pose a variety of disposal problems due to their volume, toxicity, or physical nature (e.g. fly ash, petroleum wastes, scrap tyres, rice hulls and spent coffee grounds). If these wastes could be used as low-cost adsorbents, they would provide a three-fold advantage. Firstly, the waste volume or by-products could be partly reduced, secondly, the costs for waste disposal would be reduced, and thirdly, the low-cost adsorbent (without or after modification) could reduce the contaminants of wastewaters at a reasonable cost [2]. The low-cost adsorbents provide mainly economic and environmental advantages.

Low-cost alternative adsorbents can be prepared from a wide range of raw materials. They are cheap, available in large quantities, having high organic (carbon) content, low inorganic 
content and can be easily activated. The agricultural waste or by-products (fruits and vegetable peels/stones/etc.) are the discarded waste materials which find no application anywhere. They can be used as adsorbents in their natural form or after some modification (physical or chemical) $[1,32]$. Agricultural wastes are mainly composed of lignin and cellulose, and act as attractive alternative adsorbents due to their specific structure and chemical properties. Specific functional groups such as alcohol, phenol, aldehyde, carboxyl and ketone are present in their polymer chains which help in the removal of various contaminants from water. Industrial wastes are by-products (such as fly ash, blast furnace sludge, waste slurry, lignin, iron (III) hydroxide, and red mud, coffee husks, Areca waste, tea factory waste, sugar beet pulp, waste pomace of olive oil factory waste, battery industry waste, waste biogas residual slurry, sea nodule residue, grape stalk wastes) of industries, and can be used as low-cost adsorbents for the removal of toxic metals, dyes and organic compounds from water and wastewater [1]. They require little processing to increase its adsorptive capacity [33].

Another alternative to AC is biochar. They are defined as carbonaceous by-products produced from the pyrolysis of the agricultural, forestry, industrial, and municipal biomass waste under oxygen-limited conditions [27].

Many researchers have studied adsorption of different pharmaceuticals/drugs (e.g. fluoxetine [34], sulfadiazine + sulfamethoxazole [35], paracetamol [36], acetylsalicylic acid, acetaminophen, caffeine [37], cephalexin [38], ibuprofen [4, 39, 40, 41, 42, 43]) from wastewater using various types of adsorbents (e.g. AC [36, 44], AC prepared by microwave and conventional heating methods [45], AC from Albizia lebbeck seed pods [38], AC in alginate polymer [46], potassium ferrate-activated porous graphitic biochar [47], amine functionalized superparamagnetic silica nanocomposite [48], porous carbons derived from metal-organic framework [43], silica particles [49], pyrolyzed tyre char [50], sludge-derived adsorbent [51], waste tea residue [52], acid-modified kola nut husk [53], AC from apricot stone [54], AC from peach stones [4], rice husk [55], $\mathrm{NaOH}$-activated carbon produced from macadamia nut shells [56], walnut shell-based AC [57], multi-walled carbon nanotubes [58], natural zeolite [59], etc.).

\section{WASTE-BASED ADSORBENT}

Coffee production generates a lot of by-products worldwide (e.g. spent coffee ground, coffee fruit - coffee cherry, coffee husks, peel, pulp, minor waste: defective green coffee beans, coffee tree leaves during harvest). During the extraction of the beverage from coffee powder by hot water, a large amount of residue, such as spent coffee grounds (SCG), is produced. Considering the worldwide coffee consumption, it can be concluded that tons of coffee waste are generated from cafes and domestic production. Chemical composition of coffee brews depends on the extractive efficiency, which relies on diverse factors: coffee species, roasting degree, grinding grade, coffee/water ratio, water quality, temperature, pressure and percolation time. Therefore, different extraction processes will lead to the sensorial and chemically distinct brews, and thus distinct SCG. In fact, industrially spent coffee constituents are extracted much more effectively, thus resulting in more chemically exhausted remains in comparison to the spent coffee obtained after brewing by the cafes/household environments. SCG are composed of $12.4 \%$ cellulose, $39.1 \%$ hemicellulose $(3.60 \%$ arabinose, $19.07 \%$ mannose, $16.43 \%$ galactose), $23.90 \%$ lignin, $2.29 \%$ fat, $17.44 \%$ protein, and $60.46 \%$ total dietary fibre. The differences in chemical composition of SCG presented in other papers probably reflect the variety of beans and processes used in roasting and extraction [60].

SCG can be used as a source for biodiesel production, bioethanol production, production of fuel pellets, burning fuel, source of sugars, composting material, sorbent for metal ions and dye removal, biomaterial in the pharmaceutical industry, in the food or polymer industry, 
etc. [61]. Some researchers [6, 27, 35, 37, 62, 63, 64, 65] have used SCG in different forms (e.g. raw SCG, SCG combined with chitosan and poly(vinyl alcohol), biochar from SCG, $\mathrm{NaOH}$-activated biochar from SCG, hydrochar from SCG, AC from SCG, AC from SCG with chemical activated) as adsorbent for pharmaceuticals removal (such as metamizole, acetylsalicylic acid, acetaminophen, caffeine, sulfadiazine, sulfamethoxazole, paracetamol).

Owing to the adverse effects of pharmaceuticals (mainly antibiotics and the antibiotic resistance) on aquatic organisms and the human and animal health, it is very important to pay attention to their removal from water environment. For example, tetracyclines represent a large group of antibiotics used in the human and veterinary medicine. They are also the most widely used antibiotics in the world [20,66]. Some researchers [44, 62, 63, 64, 67, 68] have studied various adsorbents for tetracycline removal.

The results of Oladipo and his team [63] have demonstrated that SCG can be exploited as resourceful raw materials. After modification of SCG, effects of composite $\mathrm{SCG} / \mathrm{Fe}_{3} \mathrm{O}_{4}(\mathrm{SCG}$ coated with $\mathrm{Fe}_{3} \mathrm{O}_{4}$ nanoparticles) dosage $\left(0.5-8 \mathrm{~g} \mathrm{~L}^{-1}\right)$, influent tetracycline concentration (50$\left.200 \mathrm{mg} \mathrm{L}^{-1}\right)$, contact time $(10-360 \mathrm{~min})$, temperature $\left(25-85^{\circ} \mathrm{C}\right)$, co-existing ions $\left(\mathrm{K}^{+}, \mathrm{Ni}^{2+}\right)$ and $\mathrm{pH}(1.0-12.0)$ on tetracycline uptake by SCG and $\mathrm{SCG} / \mathrm{Fe}_{3} \mathrm{O}_{4}$ were investigated. Column adsorption tests were conducted in a glass column (height, $40 \mathrm{~cm}$ and inner diameter, $2 \mathrm{~cm}$ ) supported by glass beads and porous sheet at both ends. Column experiments were carried out at different bed heights $(2-8 \mathrm{~cm})$, flow rates $\left(3.3-10 \mathrm{~mL} \mathrm{~min}^{-1}\right)$ and influent TC concentration (50-200 mg L $\left.\mathrm{m}^{-1}\right)$. The composite $\mathrm{SCG} / \mathrm{Fe}_{3} \mathrm{O}_{4}$ showed high adsorptive potential for tetracycline in a batch system with optimal uptake capacities of $184.5 \mathrm{mg} \mathrm{g}^{-1}$ and $285.6 \mathrm{mg} \mathrm{g}^{-1}$ for SCG and $\mathrm{SCG} / \mathrm{Fe}_{3} \mathrm{O}_{4}$, respectively. SCG coated with $\mathrm{Fe}_{3} \mathrm{O}_{4}$ nanoparticles demonstrated higher removal efficiency compared with SCG; this may be due to the presence of $\mathrm{Fe}_{3} \mathrm{O}_{4}$ in $\mathrm{SCG} / \mathrm{Fe}_{3} \mathrm{O}_{4}$ that increased its surface area. High removal efficiency $(87 \%)$ was obtained at $3.3 \mathrm{~mL} \mathrm{~min}^{-1}$ flow rate, $8.0 \mathrm{~cm}$ bed height and $50 \mathrm{mg} \mathrm{L}^{-1}$ influent tetracycline concentration in a column system. $\mathrm{SCG} / \mathrm{Fe}_{3} \mathrm{O}_{4}$ showed remarkable potential to remove antibiotics from wastewater even in the presence of toxic metal $\left(\mathrm{Ni}^{2+}\right)$ via magnetic separation. A delayed breakthrough time was obtained in the column tetracycline adsorption by increasing the bed height and decreasing the TC influent concentration and flow rate.

Some authors [62] have used SCG (SCGY: coffee Arabica beans of Yunnan Province of China, $\mathrm{SCG}_{\mathrm{H}}$ : coffee Arabica bean of Hainan Province of China) to study the adsorption of tetracycline. The results show that SCG have a great potential to be a low-cost alternative adsorbent for tetracycline removal in wastewater treatment. The study detected the effects of structural characteristics of SCG, adsorption time ( $5 \mathrm{~min}$ to $24 \mathrm{~h}$ ), initial $\mathrm{pH}(2.2-11.37)$, initial tetracycline concentration $\left(10-100 \mathrm{mg} \mathrm{L}^{-1}\right)$, amount of adsorbent $\left(0.2-1.0 \mathrm{~g} \mathrm{~L}^{-1}\right)$ and ionic strength. The results showed that the maximum removal efficiencies of tetracycline $\left(50 \mathrm{mg} \mathrm{L}^{-1}\right)$ of $\mathrm{SCG}_{Y}$ and $\mathrm{SCG}_{\mathrm{H}}$ were $97.2 \%$ and $83.1 \%$, respectively (conditions: shake for $2 \mathrm{~h}, \mathrm{pH}$ 6.5). The probability of adsorption is high and balances in about $20 \mathrm{~min}$. The effects of dosage of the SCGY on tetracycline adsorption ratio showed that with increasing the SCGY dosage, the adsorption ratio of tetracycline increased rapidly, and the adsorption ratio was constant after adding a certain dosage. When the dosage of SCGY was $0.6 \mathrm{~g} \mathrm{~L}^{-1}$, the adsorption ratio reached the maximum $\left(97.2 \%\right.$ ), and the adsorption amount was $81.0 \mathrm{mg} \mathrm{g}^{-1}$. The equilibrium data indicated that the adsorption ability was favourable and can be better described by the Langmuir model. SCGY had a strong ability to adsorb tetracycline. The saturated adsorption amounts of tetracycline by SCG were $123.46 \mathrm{mg} \mathrm{g}^{-1}$ (SCGY) and $64.89 \mathrm{mg} \mathrm{g}^{-1}$ $\left(\mathrm{SCG}_{\mathrm{H}}\right)$. Although the surface area of $\mathrm{SCG}_{\mathrm{H}}\left(451 \mathrm{~m}^{2} \mathrm{~g}^{-1}\right)$ was slightly larger than that of $\mathrm{SCG}_{\mathrm{Y}}$ $\left(419 \mathrm{~m}^{2} \mathrm{~g}^{-1}\right)$, the difference was significant for tetracycline adsorption. The adsorption capacity of tetracycline by $\mathrm{SCG}_{\mathrm{Y}}$ was almost twice as high as that of $\mathrm{SCG}_{\mathrm{H}}$.

The effect of pyrolysis temperature on polycyclic aromatic hydrocarbons production and tetracycline adsorption behaviour of biochar derived from SCG was studied by Nguyen [64]. 
To evaluate the effects of pyrolysis temperature $\left(300,500,700,900{ }^{\circ} \mathrm{C}\right)$ on adsorption capacity of biochar from SCG (bSCG), experiments were conducted under the following conditions: reaction volume of $50 \mathrm{~mL}, \mathrm{pH}$ of 7.0 , temperature of $25^{\circ} \mathrm{C}$, agitation of $100 \mathrm{rpm}$, equilibrium time of $24 \mathrm{~h}$, initial tetracycline concentration of $50 \mathrm{mg} \mathrm{L}^{-1}$, biochar dosage $1000 \mathrm{mg} \mathrm{L}^{-1}$. To evaluate effects of $\mathrm{pH}(2.0-9.0)$ and salinity (deionized water and seawater ratios of 100:0, 75:25. 50:50, 25:75, 0:100) on adsorption capacity, and determine the tetracycline adsorption isotherm of biochar (initial tetracycline concentration of $10-10 \mathrm{mg} \mathrm{L}^{-1}$ ), experiments were conducted under different conditions. The results showed that biochar synthesized at $500{ }^{\circ} \mathrm{C}$ (bSCG 500) contained low polycyclic aromatic hydrocarbons $\left(600 \mu \mathrm{g} \mathrm{kg}^{-1}\right)$ and the highest tetracycline adsorption efficiency. The highest efficiency was observed at $\mathrm{pH}$ of 7 and the presence of ions in salinity solution reduced the adsorption capacity of bSCG 500. The maximum adsorption capacity of bSCG 500 was calculated as $39.22 \mathrm{mg} \mathrm{g}^{-1}$. The results from this study demonstrate that the bSCG 500 can be used as a low-cost, environmentally friendly, and potential adsorbent for the removal of tetracycline from wastewater.

The study of Torres-Pérez [44] shows that tetracycline adsorption into AC produced from agricultural residues (sugar beet pulp, peanuts hulls) is successful. These adsorbents exhibit interesting surface properties which provide good performance in terms of the kinetic and adsorption capacities and notably, when compared with commercial AC. In this study, the batch adsorption isotherms were conducted in the synthetic and natural waters. The maximum adsorption capacities deduced from the Langmuir equation follow the sequence: $\mathrm{AC}$ commercial - AC produced by chemical activation with $\mathrm{H}_{3} \mathrm{PO}_{4}$ from wood $\left(817 \mathrm{mg} \mathrm{g}^{-1}\right)>\mathrm{AC}$ from sugar beet pulp $\left(288 \mathrm{mg} \mathrm{g}^{-1}\right)>\mathrm{AC}$ from peanut hulls $\left(28 \mathrm{mg} \mathrm{g}^{-1}\right)$. In real spring waters spiked with tetracyclines, adsorption isotherms show that the maximum adsorption capacity of AC from sugar beet pulp slightly increased to $309 \mathrm{mg} \mathrm{g}^{-1}$, while it decreased by one third to $550 \mathrm{mg} \mathrm{g}^{-1}$ in the case of AC commercial.

The study [67] used the AC prepared from the tomato industrial processing waste with $\mathrm{ZnCl}_{2}\left(\mathrm{AC}_{\mathrm{TW}}\right)$ for tetracycline adsorption. The impacts of the $\mathrm{AC}_{\mathrm{TW}}$ dosage $(10-50 \mathrm{mg})$, initial tetracycline concentration (200-400 $\left.\mathrm{mg} \mathrm{L}^{-1}\right)$, contact time (5-480 min), ionic strength and solution temperature $\left(14.85,24.85,34.85{ }^{\circ} \mathrm{C}\right)$ at $\mathrm{pH} 5.7$ were studied. Adsorption of the tetracycline increased with increased contact time, initial tetracycline concentration and solution temperature and ionic strength, while it decreased with the increase in tetracycline dosage. The equilibrium between the tetracycline ions in the solution on the $\mathrm{AC}_{\mathrm{TW}}$ surface was practically achieved in $3 \mathrm{~h}$. The maximum adsorption capacity was identified as $500.0 \mathrm{mg} \mathrm{g}^{-1}$ at $34.85{ }^{\circ} \mathrm{C}$. Results of this study indicate that the $\mathrm{AC}_{\mathrm{Tw}}$ could be employed as an adsorbent as an alternative to commercial ones for the removal of tetracycline from water and wastewater.

Results of the previous studies have showed that SCG or another waste-based adsorbent can be used as an effective adsorbent for tetracycline removal when compared to the other ones reported in literature studies. Studies have also showed that adsorption capacity of tetracycline depends on various parameters (such as type of adsorbent, method of adsorbent treatment, conditions of treatment, $\mathrm{pH}$ ), not only on surface area. The results of [62] indicate that the adsorption capacity of SCG to tetracycline depends mainly on the chemical properties of the surface rather than the surface area. The adsorption experimental results in [68] suggest that efficient adsorption of tetracycline on biochar can be achieved by enlarging their surface area and also optimizing their pores. Study of [63] shows that modification of SCG with $\mathrm{Fe}_{3} \mathrm{O}_{4}$ particles has led to increased surface area and availability of more adsorption sites. Results in [64] showed that the pyrolysis temperature during biochar production is very important. The pyrolysis temperature affects the surface structure and forms of the functional group of biochar, which are decisive factors for the ability of biochar to adsorb contaminants. Also, $\mathrm{pH}$ is a very important factor for adsorption, as it affects the surface charge of adsorbent and forms of 
tetracycline in solution (tetracycline exists in a cationic form at low $\mathrm{pH}$ conditions $<3.3$, zwitter anion at $3.3<\mathrm{pH}<7.7$ and anion form at $\mathrm{pH}>7.7$ ), etc.

The results of surface area $\left(\mathrm{S}_{\mathrm{BET}}\right)$, pore volume and adsorption capacity from these studies are shown in Table 2.

Table 2 Results of various studies of various adsorbents for tetracycline removal

\begin{tabular}{|c|c|c|c|c|c|}
\hline Adsorbents & $\begin{array}{c}\text { SBEt } \\
{\left[\mathbf{m}^{2} \mathbf{g}^{-1}\right]}\end{array}$ & $\begin{array}{l}\text { Pore volume } \\
\qquad\left[\mathrm{cm}^{3} \mathrm{~g}^{-1}\right]\end{array}$ & $\begin{array}{c}\text { Adsorption } \\
\text { capacity } \\
{\left[\mathrm{mg} \mathrm{g}^{-1}\right]}\end{array}$ & $\begin{array}{c}\text { Adsorption } \\
\text { model isotherm }\end{array}$ & Source \\
\hline SCG & 23.55 & 0.26 & 184.5 & - & [63] \\
\hline $\mathrm{SCG}_{\mathrm{Y}}$ & 419 & 0.23 & 123.46 & Langmuir & [62] \\
\hline $\mathrm{SCG}_{\mathrm{H}}$ & 451 & 0.27 & 64.89 & Langmuir & [62] \\
\hline $\mathrm{SCG} / \mathrm{Fe}_{3} \mathrm{O}_{4}$ & 86.34 & 0.54 & 285.6 & Langmuir & [63] \\
\hline bSCG 500 & - & - & 39.22 & Langmuir & [64] \\
\hline Biochar & 34.4 & 0.028 & 16.95 & Langmuir & [68] \\
\hline Acid biochar & 46.8 & 0.033 & 23.26 & Langmuir & {$[68]$} \\
\hline Alkali biochar & 117.8 & 0.073 & 58.82 & Langmuir & [68] \\
\hline $\mathrm{AC}_{\mathrm{TW}}$ & 1093 & 1.569 & 500 & Langmuir & [67] \\
\hline AC sugar beet pulp & 821 & 0.6430 & 288 & Langmuir & [44] \\
\hline AC peanut hulls & 829 & 0.4028 & 28 & Langmuir & [44] \\
\hline AC commercial & 1515 & 1.2291 & 817 & Langmuir & [44] \\
\hline
\end{tabular}

$S_{B E T}-$ BET-surface area; $S C G_{Y}-S C G$ from coffee arabica beans of Yunnan Province of China; $S C G_{H}-S C G$ from coffee arabica bean of Hainan Province of China; $\mathrm{SCG} / \mathrm{Fe}_{3} \mathrm{O}_{4}-\mathrm{SCG}$ coated with $\mathrm{Fe}_{3} \mathrm{O}_{4}$ nanoparticles; bSCG 500 - biochar from $\mathrm{SCG}$ synthesized at $500{ }^{\circ} \mathrm{C}$; acid biochar - biochar activated with $\mathrm{H}_{2} \mathrm{SO}_{4}$; alkali biochar - biochar activated with $\mathrm{KOH} ; \mathrm{AC}_{T W}-\mathrm{AC}$ prepared from tomato industrial processing waste with $\mathrm{ZnCl}_{2}$; $\mathrm{AC}$ commercial - AC produced by chemical activation with $\mathrm{H}_{3} \mathrm{PO}_{4}$ from wood

The high cost of commercial adsorbents is the main disadvantage to their application in large scale (especially for developing countries) although they provide high removal rates. Therefore, the search for alternative low-cost adsorbents is an urgent need. [6] Total coffee year production was approximately 171 million bags $(1 \mathrm{bag}=60 \mathrm{~kg}$ ) in 2020 (\% change 2019-2020 is $+1.9 \%$ ) [69]. About $0.91 \mathrm{~g} \mathrm{SCG}$ are produced per $1 \mathrm{~g}$ of ground coffee [60]. The European Union is by far the biggest importer and consumer of coffee, where most of the SCG is currently being incinerated or disposed of in landfills [6]. The information about the total year coffee production shows how much waste (SCG) is produced every year. The performed studies have revealed that SCG can be used as a potential tetracycline adsorbent although adsorption capacity is usually lower in comparison to commercial adsorbents (e.g. activated carbon). The study of [6] points out that the adsorption capacity is not the only most important parameter to evaluate the adsorption process. In this study, cost of fluoxetine removed by waste-based adsorbents (SCG, cork waste, pine bark) and commercial adsorbents (granular activated carbon, granules of $2.5 \mathrm{~mm}$, Merck) is examined through a detailed cost analysis (Table 3).

Table 3 Comparison of adsorption capacity and cost per gram of fluoxetine removed by various adsorbents [6]

\begin{tabular}{|l|c|c|c|c|}
\hline \multicolumn{1}{|c|}{ Adsorbents } & $\begin{array}{c}\mathbf{S}_{\text {BET }} \\
{\left[\mathbf{m}^{\mathbf{2}} \mathbf{g}^{-\mathbf{1}}\right]}\end{array}$ & $\begin{array}{c}\text { Adsorption capacity } \\
{\left[\mathbf{m g ~ g}^{-\mathbf{1}}\right]}\end{array}$ & $\begin{array}{c}\text { Adsorption model } \\
\text { isotherm }\end{array}$ & $\begin{array}{c}\text { Cost } \\
{\left[\mathbf{\epsilon ~}^{-\mathbf{1}}\right]}\end{array}$ \\
\hline SCG & $<4$ & 14.31 & Sips & 0.16 \\
\hline Cork waste & $<4$ & 4.74 & Sips & 0.41 \\
\hline Pine bark & $<4$ & 6.53 & Sips & 0.92 \\
\hline Granular AC & 1095 & 233.5 & Langmuir & 1.07 \\
\hline
\end{tabular}




\begin{tabular}{|l|c|c|c|c|}
\hline Zeolite $13 \times$ & 576 & 32.11 & Langmuir & 3.13 \\
\hline Zeolite $4 \mathrm{a}$ & 38.4 & 21.86 & Langmuir & 6.85 \\
\hline
\end{tabular}

Waste-based adsorbents showed lower adsorption capacities $\left(4.74-14.31 \mathrm{mg} \mathrm{g}^{-1}\right)$ in comparison to commercial adsorbents $\left(21.86-233.5 \mathrm{mg} \mathrm{g}^{-1}\right)$. In terms of cost per gram of fluoxetine removed, commercial adsorbents present higher costs (1.07-6.85 $€ \mathrm{~g}^{-1}$ ) when compared to waste-based adsorbents $\left(0.16-0.92 € \mathrm{~g}^{-1}\right)$. SCG is the most economical adsorbent, while cork waste is the most environmentally-friendly, since its preparation represents a reduced environmental impact, without the generation of solid or liquid wastes. Results of [6] indicate that the used waste-based adsorbents with lower adsorption capacity have a big advantage - low cost of removed fluoxetine. Therefore, the waste-based adsorbents may be successfully applied as low-cost adsorbent.

The amounts of natural wastes or by-products from the industrial processing of agroindustry products represent an issue for the producing countries, because their disposal is expensive and can severely impact the environment [70]. Currently, it is urgent to implement sustainable waste management procedures in order to reduce waste and improve environmental health. Most wastes still represent valuable resources of unexploited economic value. In this terms, transition from the linear economy to the circular economy concept (that implies the materials' recycling and their return to the industry or market) has been gaining acceptance worldwide. Circular economy (arisen from the 3 R's Rule: Reduce, Reuse and Recycle) puts great emphasis to the zero-waste approach and the exploitation of renewable resources [71]. The use of waste materials (such as SCG, cork waste, sugar beet pulp, pine bark, peanut hulls) as adsorbents is in line with the concept of circular economy and with an increasingly stringent environmental regulation that discourages disposal practices such as landfilling and incineration. The aim of converting these waste materials (low-cost and profusely available) into adsorbents is improves waste management and protects the environment [6].

\section{CONCLUSION}

Water is a natural resource needed by all living creatures. Clean water is also used in manufacturing and for the social and economic development. Water pollution is one of the main environmental issues that we face. There are many man-made pollutants (e.g. toxic metals, pharmaceuticals, dyes) that can contaminate water sources and cause water pollution. For example, wastewater from homes and pharmaceutical industry typically goes to WWTPs. Some of the compounds in the water might be biologically active, toxic, or persistent and most of those cannot be sufficiently removed using conventional water treatment processes in WWTPs before the treated water is discharged into streams or rivers. Therefore, it is necessary to improve treatment processes in WWTPs and adapt them to the new types of contaminants (such as pharmaceuticals and their residues) in wastewater. Removal of pharmaceuticals by adsorption is one of the most attractive methods for the treatment of water environment, which is due to its versatility, low energy consumption, simplicity, and high efficiency in the removal of contaminants. Today, agricultural or industrial activities generate a huge amount of solid waste materials as by-products. While some of these are reused, others are sent for disposal in landfills. Therefore, the possibility of reuse in adsorption processes represents an interesting solution mainly because these industrial waste materials are available almost free of charge and they represent a major disposal problem. The results of many studies have showed that wastebased material had a great potential to be a cost-effective, environmentally-friendly, and a potential adsorbent for removal of pharmaceuticals in wastewater treatment. 


\section{References}

[1] SINGH, N. B. et al. 2018. Water purification by using Adsorbents: A Review. Environmental Technology and Innovation, 11, 187-240. ISSN 2352-1864.

[2] DE GISI, S. et al. 2016. Characteristics and adsorption capacities of low-cost sorbents for wastewater treatment: A review. Sustainable Materials and Technologies, 9, 10-40. ISSN 22149937.

[3] KARIMI-MALEH, H. et al. 2021. Recent advances in using of chitosan-based adsorbents for removal of pharmaceutical contaminants: A review. Journal of Cleaner Production, 291, 125880. ISSN 0959-6526.

[4] ÁLVAREZ-TORRELLAS, S. et al. 2016. Comparative adsorption performance of ibuprofen and tetracycline from aqueous solution by carbonaceous materials. Chemical Engineering Journal, 283, 936-947. ISSN 1385-8947.

[5] BASHEER, A. A. 2018. New generation nano-adsorbents for the removal of emerging contaminants in water. Journal of Molecular Liquids, 261, 583-593. ISSN 0167-7322.

[6] SILVA, B. et al. 2020. Waste-based biosorbents as cost-effective alternatives to commercial adsorbents for the retention of fluoxetine from water. Separation and Purification Technology, 235, 116139, ISSN 1383-5866.

[7] WHO, Information sheet: Pharmaceuticals in drinking-water [Online]. [Accessed: 02-2021] Available at https://www.who.int/water_sanitation_health/diseasesrisks/risks/info_sheet_pharmaceuticals/en/.

[8] Britannica, The Editors of Encyclopaedia. Pharmaceutical. Encyclopedia Britannica [Online]. [Accessed: 02-2021] Available at https://www.britannica.com/technology/pharmaceutical.

[9] OLUWOLE, A. O. et al. 2020. Pharmaceuticals and personal care products in water and wastewater: a review of treatment processes and use of photocatalyst immobilized on functionalized carbon in AOP degradation. BMC Chemistry, 14 (62), 29. ISSN 2661-801X.

[10] LIU, J. L., WONG, M. H. 2013. Pharmaceuticals and personal care products (PPCPs): A review on environmental contamination in China. Environment International, 59, 208-224, ISSN 01604120.

[11] MIKULIC, M. Global Pharmaceutical Industry - Statistics \& Facts [Online]. 2020. [Accessed: 022021] Available at https://www.statista.com/topics/1764/global-pharmaceutical-industry/.

[12] www.statista.com, Revenue of the worldwide pharmaceutical market from 2001 to 2019 [Online]. [Accessed: 02-2021] Available at https://www.statista.com/statistics/263102/pharmaceuticalmarket-worldwide-revenue-since-2001/.

[13] www.globenewswire.com, Global Pharmaceuticals Industry Analysis and Trends 2023 [Online]. 2020 [Accessed: 02-2021] Available at https://www.globenewswire.com/newsrelease/2020/01/17/1972092/0/en/Global-Pharmaceuticals-Industry-Analysis-and-Trends2023.html.

[14] OECD. 2019. Pharmaceutical Residues in Freshwater: Hazards and Policy Responses. preliminary version. Paris : OECD Publishing, 2019. 20 p. ISBN 978-92-6-477633-3.

[15] WHO. 2012. Pharmaceuticals in drinking-water. 2012, 52 p. ISBN 978-92-4-150208-5.

[16] KANAMA, K. M. et al. 2018. Assessment of pharmaceuticals, personal care products, and hormones in wastewater treatment plants receiving inflows from health facilities in North West Province, South Africa. Journal of Toxicology, 2018, 15. ISSN 1687-8191.

[17] KYZAS, G. Z. et al. 2015. New approaches on the removal of pharmaceuticals from wastewaters with adsorbent materials. Journal of Molecular Liquids, 209, 87-93. ISSN 0167-7322.

[18] SHARMA, V. K. et al. 2016. A review of the influence of treatment strategies on antibiotic resistant bacteria and antibiotic resistance genes. Chemosphere, 150, 702-714. ISSN 0045-6535.

[19] WHO, Antibiotic resistance [Online]. 2020 [Accessed: 02-2021] Available at https://www.who.int/news-room/fact-sheets/detail/antibiotic-resistance.

[20] KLEIN, E. Y. et al. 2020. Assessment of WHO antibiotic consumption and access targets in 76 countries, 2000-15: an analysis of pharmaceutical sales data. The Lancet Infectious Diseases, 21, 107-115. ISSN 1473-3099.

[21] KAUR, H. et al. 2019. Treatment methods for removal of pharmaceuticals and personal care products from domestic wastewater. Vara Prasad, M. N. et al. (eds.). Pharmaceuticals and Personal 
Care Products: Waste Management and Treatment Technology. Elsevier, 2019. 129-150. ISBN 978-0-12-816189-0.

[22] KHADIR, A. et al. 2020. A Review on Pharmaceutical Removal from Aquatic Media by Adsorption: Understanding the Influential Parameters and Novel Adsorbents. Inamuddin, A. M. Asiri (eds.). Sustainable Green Chemical Processes and their Allied Applications, Nanotechnology in the Life Sciences. Springer Nature Switzerland AG 2020. 59. ISBN 978-3-030-42284-4.

[23] GUO, Y. et al. 2017. A Review on Advanced Treatment of Pharmaceutical Wastewater. In: IOP Conf. Ser.: Earth and Environmental Science. 63. International Conference on Environmental and Energy Engineering (IC3E 2017): China, Suzhou, pp. 170-176. ISBN 978-1-5108-4038-6.

[24] LI, X., LI, G. 2015. A Review: Pharmaceutical Wastewater Treatment Technology and Research in China. In: Advances in Engineering Research. Asia-Pacific Energy Equipment Engineering Research Conference (AP3ER 2015). pp. 345-348. ISBN 978-94-62520-63-9.

[25] FANOURAKIS, S. K. et al. 2020. Nano-based adsorbent and photocatalyst use for pharmaceutical contaminant removal during indirect potable water reuse. npj Clean Water, 3(1), 1-15. ISSN 20597037.

[26] NAZAL, M. K. 2020. An Overview of Carbon-Based Materials for the Removal of Pharmaceutical Active Compounds. Bartoli, M. et al. (eds.). Carbon-Based Material for Environmental Protection and Remediation, IntechOpen, ISBN: 978-1-83968-442-5.

[27] SHIN, J. et al. 2021. Competitive adsorption of pharmaceuticals in lake water and wastewater effluent by pristine and $\mathrm{NaOH}$-activated biochars from spent coffee wastes: Contribution of hydrophobic and $\pi-\pi$ interactions. Environmental Pollution, 270, 116244, 2021. ISSN 0269-7491.

[28] CRINI, G. et al. 2019. Conventional and non- conventional adsorbents for wastewater. Environmental Chemistry Letters, 17(1), 195-213. ISSN 1610-3661.

[29] CRINI, G., LICHTFOUSE, E. 2019. Advantages and disadvantages of techniques used for wastewater treatment. Environmental Chemistry Letters, 17(1), 145-155. ISSN 1610-3661.

[30] SADEGH, H., ALI, G. A. M. 2018. Potential Applications of Nanomaterials in Wastewater Treatment: Nanoadsorbents Performance. Hussain, A., Ahmed, S. (eds.). Advanced Treatment Techniques for Industrial Wastewater. IGI Global, 2018. 51-61 p. ISBN 978-1522557548.

[31] ARIFFIN, N. et al. 2017. Review on Adsorption of Heavy Metal in Wastewater by Using Geopolymer. In: MATEC Web Conf. Engineering Technology International Conference 2016 (ETIC 2016). 97, pp. 1-8. eISSN: 226-236X.

[32] BHATNAGAR, A., SILLANPÄÄ, M. 2010. Utilization of agro-industrial and municipal waste materials as potential adsorbents for water treatment-A review. Chemical Engineering Journal, 157. 277-296. ISSN 1385-8947.

[33] AHMARUZZAMAN, M. 2011. Industrial wastes as low-cost potential adsorbents for the treatment of wastewater laden with heavy metals. Advances in Colloid and Interface Science, 166, 36-59. ISSN 0001-8686.

[34] SILVA, B. et al. 2018. Valorization of spent coffee grounds as biosorbent for the retention of fluoxetine from water - a cost-effective alternative to activated carbon. In: CHEMPOR 2018. 13th International Chemical and Biological Engineering Conference. 132-133. ISBN 978-972-789-5663.

[35] ZHANG, X. et al. 2020. Characterization and sulfonamide antibiotics adsorption capacity of spent coffee grounds based biochar and hydrochar. Science of the Total Environment, 716, 137015. ISSN 0048-9697.

[36] BURSZTYN FUENTES, A. L. et al. 2020. Paracetamol removal by Kon-Tiki kiln-derived biochar and activated carbons. Industrial Crops \& Products journal, 155, 112740. ISSN 0926-6690.

[37] LESSA, E. F. et al. 2018. Chitosan/waste coffee-grounds composite: An efficient and eco-friendly adsorbent for removal of pharmaceutical contaminants from water. Carbohydrate Polymers journal, 189, 257-266. ISSN 0144-8617.

[38] AHMED, M. J., THEYDAN, S. K. 2012. Adsorption of cephalexin onto activated carbons from Albizia lebbeck seed pods by microwave-induced $\mathrm{KOH}$ and $\mathrm{K}_{2} \mathrm{CO}_{3}$ activations," Chemical Chemical Engineering Journal, 211-212, 200-207. ISSN 1385-8947.

[39] MESTRE, A. S. et al. 2014. Activated carbons prepared from industrial pre-treated cork: Sustainable adsorbents for pharmaceutical compounds removal. Chemical Engineering Journal, 253, 408-417, ISSN 1385-8947. 
[40] REZA, R. A. et al. 2014. Comparative adsorption behavior of ibuprofen and clofibric acid onto microwave assisted activated bamboo waste. Industrial \& Engineering Chemistry Research, 53(22), 9331-9339. ISSN 1520-5045.

[41] DUBEY, S. P. et al. 2014. Raspberry derived mesoporous carbon-tubules and fixed-bed adsorption of pharmaceutical drugs. Journal of Industrial and Engineering Chemistry, 20(3), 1126-1132. ISSN 1226-086X.

[42] PUSZKAREWICZ, A. et al. 2017. Application of powdery activated carbons for removal ibuprofen from water. Journal of Ecological Engineering, 18(4), 169-177. ISSN 2299-8993.

[43] BHADRA, B. N. et al. 2017. Adsorptive removal of ibuprofen and diclofenac from water using metal-organic framework-derived porous carbon. Chemical Engineering Journal, 314, 50-58. ISSN 1385-8947.

[44] TORRES-PÉREZ, J. et al. 2012. Sustainable activated carbons from agricultural residues dedicated to antibiotic removal by adsorption. Chinese Journal of Chemical Engineering, 20(3), 524-529. ISSN 1004-9541.

[45] HUANG, L. et al. 2011. Comparative study on characterization of activated carbons prepared by microwave and conventional heating methods and application in removal of oxytetracycline (OTC). Chemical Engineering Journal, 171, 1446-1453. ISSN 1385-8947.

[46] ABDEL-GAWAD, S. A., ABD EL-AZIZ, H. M. 2019. Removal of Pharmaceuticals From Aqueous Medium Using Entrapped Activated Carbon in Alginate. Air, Soil and Water Research, 12, 1-7. ISSN 1178-6221.

[47] TAM, N. T. M. et al. 2020. Efficient removal of diclofenac from aqueous solution by potassium ferrate-activated porous graphitic biochar: Ambient condition influences and adsorption mechanism. International Journal of Environmental Research and Public Health Article, 17, 1-22. ISSN 1660-4601.

[48] CHANDRASHEKAR KOLLARAHITHLU, S., BALAKRISHNAN, R. M. 2021. Adsorption of pharmaceuticals pollutants, Ibuprofen, Acetaminophen, and Streptomycin from the aqueous phase using amine functionalized superparamagnetic silica nanocomposite. Journal of Cleaner Production journal, 294, 126155. ISSN 0959-6526.

[49] TURKU, I. et al. 2007. Thermodynamics of tetracycline adsorption on silica. Environmental Chemistry Letters, 5, 225-228. ISSN 1610-3661.

[50] ACOSTA, R. et al. 2016. Tetracycline adsorption onto activated carbons produced by $\mathrm{KOH}$ activation of tyre pyrolysis char. Chemosphere, 149, 168-176. ISSN 0045-6535.

[51] RIVERA-UTRILLA, J. et al. 2013. Tetracycline removal from water by adsorption/bioadsorption on activated carbons and sludge-derived adsorbents. Journal of Environmental Management, 131, 16-24. ISSN 0301-4797.

[52] PATIL, C. S. et al. 2019. Waste tea residue as a low cost adsorbent for removal of hydralazine hydrochloride pharmaceutical pollutant from aqueous media: An environmental remediation. Journal of Cleaner Production journal, 206, 407-418. ISSN 0959-6526.

[53] BELLO, O. S. et al. 2021. A renewable, sustainable and low-cost adsorbent for Ibuprofen removal. Water Science \& technology, 83(1), 111-122. ISSN 0273-1223.

[54] ALJEBOREE, A. M. 2020. Low cost adsorbents for the removal of pharmaceutical pollutants from aqueous solution: Thymine drug as a model. In: Journal of Physics: Conference Series. 1st International Virtual Conference on Pure Science: Iraq, 1664, pp. 0-9.

[55] REDDY, Y. G. et al. 2017. Low cost adsorbents utilization for the treatment of pharmaceutical wastewater. International Journal of Civil Engineering Research, 8(1), 39-48. ISSN 2278-3652.

[56] MARTINS, A. C. et al. 2015. Removal of tetracycline by $\mathrm{NaOH}$-activated carbon produced from macadamia nut shells: Kinetic and equilibrium studies. Chemical Engineering Journal journal, 260, 291-299. ISSN 1385-8947.

[57] NAZARI, G. et al. 2016. Batch adsorption of cephalexin antibiotic from aqueous solution by walnut shell-based activated carbon. Journal of the Taiwan Institute of Chemical Engineers, 58, 357-365, ISSN 1876-1070.

[58] ZHANG, L. et al. 2011. Studies on the removal of tetracycline by multi-walled carbon nanotubes. Chemical Engineering Journal, 178, 26-33. ISSN 1385-8947. 
[59] AL-RIMAWI, F. et al. 2019. Removal of Selected Pharmaceuticals from Aqueous Solutions Using Natural Jordanian Zeolite. Arabian Journal for Science and Engineering, 44, 209-215. ISSN 21914281.

[60] BLINOVÁ, L., SIROTIAK, M. 2019. Utilization of Spent Coffee Grounds for Removal of Hazardous Substances from Water: A Review. Research Papers Faculty of Materials Science and Technology Slovak University of Technology, 27(44), 145-152. ISSN 1338-0532.

[61] BLINOVÁ, L. et al. 2017. Review : Utilization of Waste From Coffee Production. Research Papers Faculty of Materials Science and Technology Slovak University of Technology, 25(40), 91-102. ISSN 1338-0532.

[62] DAI, Y. et al. 2019. New use for spent coffee ground as an adsorbent for tetracycline removal in water. Chemosphere, 215, 163-172. ISSN 0045-6535.

[63] OLADIPO, A. A. et al. 2016. Bifunctional composite from spent 'Cyprus coffee' for tetracycline removal and phenol degradation: Solar-Fenton process and artificial neural network. International Journal of Biological Macromolecules, 90, 89-99. ISSN 0141-8130.

[64] NGUYEN, V. T. et al. 2019. Influence of pyrolysis temperature on polycyclic aromatic hydrocarbons production and tetracycline adsorption behavior of biochar derived from spent coffee ground. Bioresource Technology journal, 284, 197-203. ISSN 0960-8524.

[65] BENYEKKOU, N. et al. 2020. Elimination of paracetamol from water by a spent coffee grounds biomaterial. Environmental Nanotechnology, Monitoring \& Management, 14, 100396. ISSN 22151532.

[66] TONG, X. et al. 2016. Insights into the interactions between tetracycline, its degradation products and bovine serum albumin. Springerplus, 5. ISSN 2193-1801.

[67] SAYĞILI, H., GÜZEL, F. 2016. Effective removal of tetracycline from aqueous solution using activated carbon prepared from tomato (Lycopersicon esculentum Mill.) industrial processing waste. Ecotoxicology and Environmental Safety, 131, 22-29. ISSN 0147-6513.

[68] LIU, P. et al. 2012. Modification of bio-char derived from fast pyrolysis of biomass and its application in removal of tetracycline from aqueous solution. Bioresource Technology, 121, 235240. ISSN 0960-8524.

[69] www.ico.org, Coffee production by exporting countries [Online]. [Accessed: 02-2021] Available at http://www.ico.org/prices/po-production.pdf

[70] RICCIARDI, P. et al. 2020. Valorization of agro-industry residues in the building and environmental sector: A review. Waste Management \& Research, 38(5), 487-513. ISSN 0734$242 \mathrm{X}$

[71] SILVA, C. P. et al. 2018. Waste-based alternative adsorbents for the remediation of pharmaceutical contaminated waters: Has a step forward already been taken?. Bioresource Technology, 250, 888901. ISSN 0960-8524.

\section{ORCID}

Lenka Blinová 0000-0001-6971-6558

Maroš Sirotiak 0000-0003-1487-801X 